\title{
ANALISIS PENGARUH FAKTOR FUNDAMENTAL EKONOMI MAKRO DAN HARGA MINYAK TERHADAP SAHAM LQ45 DALAM JANGKA PENDEK DAN JANGKA PANJANG
}

\author{
Dwi Wahyu Prasetiono \\ Alumni Fakultas Ekonomi Universitas Brawijaya
}

\begin{abstract}
The objective of this research was to examine the macro economics factors and the price of crude oil that influencing $L Q 45$ stock price in the short and long run. There were four fundemntal macro economics variabel in this study such as economic growth, $S B I$ rate, and exchange rate wich used with crude oil price to examine their influence to LQ45 Stock price. This study used Error Correction Model to analyse the problem. The result show that in the short run, economic growth and crude oil price have influence to LQ45 stock price. Furthermore, in the long run economic groth, SBI rate have influence to LQ45 stock price.
\end{abstract}

Keywords: LQ45 stock price, macro economics variables, crude oil, and ECM

\section{A. LATAR BELAKANG}

Kondisi pasar modal yang mengalami pasang surut memperlihatkan bahwa kegiatan di pasar modal mempunyai hubungan yang erat dengan kondisi ekonomi makro, karena itu kondisi ekonomi makro yang stabil merupakan pendorong bagi berkembangnya pasar modal. Pertumbuhan ekonomi biasanya diukur dari pertambahan Gross Domestic Product (GDP). Besarnya tingkat pertumbuhan ekonomi menunjukkan besarnya pertumbuhan dalam produk dan jasa. Apabila pertumbuhan ini terus berlangsung maka kegiatan investasi sangat diperlukan untuk menunjang peningkatan dalam kegiatan produksi yang selanjutnya memberikan perkembangan yang baik bagi pasar modal sebagai sumber dana bagi pengembangan dunia usaha.

Secara umum investasi merupakan komitmen sejumlah dana untuk tujuan mendapatkan keuntungan di masa yang akan datang. Semakin menjanjikannya dunia pasar modal menyebabkan banyak orang tertarik untuk melakukan investasi di dunia pasar modal. Kondisi yang terjadi di pasar modal diawasi oleh suatu badan yang disebut dengan BAPEPAM (Badan Perencana dan Pengawas Pasar Modal). Sebagai lembaga atau otoritas tertinggi di pasar modal Indonesia, melakukan pengelompokan terhadap 45 saham yang memilki tingkat likuiditas perdagangan di atas rata-rata tingkat likuiditas saham lainnya yang terdaftar di Bursa Efek Jakarta. Saham-saham tersebut dinamakan LQ45, yaitu 45 saham yang dipilih berdasarkan likuiditas perdagangan saham dan disesuaikan setiap 6 bulan (setiap awal Februari dan Agustus).

Saham perusahaan yang terdaftar dalam LQ45 merupakan saham yang aktif diperdagangkan dan harganya terus berfluktuasi seiring dengan intensitas perdagangannya. Indeks ini mencakup 45 saham yang diseleksi berdasarkan kriteria spesifik tertentu untuk menjamin bahwa indeks tersebut hanya menyajikan saham-saham yang paling likuid dan memiliki tingkat kapitalisasi pasar yang besar serta banyak diminati oleh para investor di pasar modal. Dengan tingkat likuiditas ini, membuat investor banyak meminati saham-saham LQ45, hal inilah yang mendasari penulis mengambil sampel LQ45 dan bukan kelompok saham lain ataupun IHSG.

Dari uraian diatas, rumusan masalah dalam penelitian ini adalah bagaimana pengaruh faktor 
fundamental ekonomi makro dalam hal ini adalah pertumbuhan ekonomi, tingkat bunga SBI dan nilai tukar (kurs) serta faktor harga minyak terhadap saham LQ45 baik dalam jangka pendek maupun jangka panjang.

\section{B. KAJIAN TEORITIS}

\section{Hubungan antara Tingkat Bunga SBI dengan Harga Saham}

Pada penelitian ini, tingkat bunga yang dimaksud adalah tingkat bunga pada SBI. Dimana SBI merupakan instrument Bank Sentral sebagai lender of the resort yang hanya dimanfaatkan jika bank-bank sudah terdesak. Besarnya fasilitas diskonto disesuaikan dengan besarnya dana yang ada di masyarakat. Dalam hal ini SBI bisa diartikan sebagai instrumen kontraksi moneter yang bisa digunakan Bank Indonesia jika situasi moneter dinilai ekspansif (Rahardjo, 1995).

Tingkat pengembalian yang diharapkan investor pada investasi saham seringkali dipengaruhi oleh pendapatan yang diperoleh investor pada alternatif investasi lain. Weston dan Brigham (1990) berpendapat bahwa tingkat bunga mempengaruhi harga saham dengan 2 cara, yaitu:

1. Tingkat bunga mempengaruhi laba perusahaan karena tingkat bunga merupakan biaya.

2. Tingkat bunga yang tinggi akan menyebabkan investor menarik investasi sahamnya dan memindahkannya pada investasi lain yang menawarkan tingkat bunga yang lebih tinggi.

\section{Hubungan antara Kurs dengan Harga Saham}

Kurs atau nilai tukar valuta asing menurut Dahlan (2001) adalah harga suatu mata uang yang dinyatakan dalam harga mata uang lain. Misalnya kurs rupiah atas dolar AS menunjukkan nilai rupiah yang diperlukan untuk setiap dolar AS. Perubahan kurs rupiah atas dolar AS berdampak berbeda terhadap setiap jenis saham, artinya suatu saham terkena dampak positif sedangkan saham lainnya terkena dampak negatif. Contoh kenaikan tajam kurs USD terhadap rupiah akan berdampak negatif terhadap emiten yang memiliki hutang dolar sementara produk emiten tersebut dijual lokal, sedangkan emiten yang berorientasi pada kegiatan ekspor akan menerima dampak positif dari kenaikan kurs USD tersebut sehingga mengakibatkan kenaikan pada harga saham.

\section{Hubungan antara Pertumbuhan Ekonomi dengan Harga Saham}

Pertumbuhan ekonomi adalah proses dimana terjadi kenaikan produk nasional bruto riil atau pendapatan nasional riil. Jadi, perekonomian dikatakan tumbuh atau berkembang bila terjadi pertumbuhan output riil. Definisi pertumbuhan ekonomi yang lain adalah bahwa pertumbuhan ekonomi terjadi bila ada kenaikan output perkapita. Pertumbuhan ekonomi menggambarkan kenaikan taraf hidup diukur dengan output riil per orang. Salah satu indikator dari pertumbuhan ekonomi suatu negara adalah Gross Domestic Product (GDP). Jika pertumbuhan ekonomi membaik, maka daya beli masyarakat akan meningkat pula dan hal ini memberikan kesempatan pada perusahaan untuk meningkatkan penjualannya. Dengan meningkatnya penjualan maka kesempatan memperoleh laba juga akan mengalami peningkatan (Tandelilin, 2001).

\section{Hubungan antara Harga Minyak dengan Harga Saham}

Kenaikan harga minyak dunia bisa memberikan dampak berbeda pada setiap harga saham, yaitu saham dari perusahaan yang bergerak di bidang pertambangan dan perusahaan yang bergerak di luar bidang pertambangan. Pada perusahaan non pertambangan, kenaikan harga minyak bisa membawa dampak negatif karena akan mengakibatkan kenaikan biaya produksi dan secara tidak langsung akan menurunkan harga saham. Sedangkan pada perusahaan pertambangan kenaikan harga minyak membawa dampak positif pada penerimaan yang akan diperoleh yang akan mengakibatkan kenaikan harga saham. 


\section{Analisis Pengaruh Faktor Fundamental Ekonomi}

Prasetiono

\section{Penelitian Terdahulu}

Penelitian Banerjee dan Bishnu (2007) yang dilakukan di pasar saham di Bangladesh yang meneliti tentang hubungan antara nilai tukar dan suku bunga dengan harga saham. Hasil yang diperoleh adalah bahwa dalam jangka pendek nilai tukar dan suku bunga tidak memiliki pengaruh yang signifikan. Pengaruh yang signifikan terlihat pada jangka panjang. Persamaan penelitian dengan penelitian sebelumnya adalah bahwa dalam penelitian ini penulis menggunakan variabel nilai tukar dan tingkat suku bunga dalam upaya mengetahui pengaruhnya terhadap harga saham. Perbedaan dengan penelitian ini adalah dalam hal tempat penelitian, jumlah variabel yang digunakan serta alat analisis yang digunakan.

Selanjutnya penelitian yang dilakukan Kaluge (2006) meneliti tentang pengaruh profitabilitas, suku bunga, GDP dan kurs terhadap harga saham dengan pendekatan Error Correction Model. Kesimpulan yang dapat diperoleh adalah secara simultan semua variabel yang dipakai dalam penelitian dapat digunakan untuk memprediksi harga saham. Namun secara parsial, variabel yang memiliki pengaruh signifikan terhadap harga saham adalah variabel profitabilitas dan kurs atau nilai tukar. Persamaan dengan penelitian ini adalah penggunaan faktor fundamental makro GDP, suku bunga dan nilai tukar. Selain itu juga adalah penggunaan pendekatan Error Correction Model sebagai alat analisis. Perbedaannya adalah penelitian ini sampel yang digunakan adalah saham LQ45, sedangkan penelitian yang dilakukan oleh Kaluge (2006) mengambil sampel PT. Gudang Garam Tbk. Selain itu peneliti juga menambahkan variabel harga minyak sebagai variabel independen.

\section{Hipotesis}

Berdasarkan latar belakang dan tinjauan pustaka, maka dapat diambil jawaban sementara atau hipotesa, yaitu:

1. Diduga variabel pertumbuhan ekonomi berpengaruh positif dan signifikan terhadap saham dalam jangka pendek dan jangka panjang.

2. Diduga variabel suku bunga SBI berpengaruh negatif dan signifikan terhadap saham dalam jangka pendek dan jangka panjang.

3. Diduga variabel kurs berpengaruh negatif dan signifikan terhadap saham dalam jangka pendek dan jangka panjang.

4. Diduga variabel harga minyak berpengaruh positif dan signifikan terhadap saham dalam jangka pendek dan jangka panjang.

\section{METODE DAN ANALISIS DATA}

\section{Jenis Penelitian}

Dilihat dari pendekatan analisisnya, pendekatan yang digunakan dalam penelitian ini adalah pendekatan kuantitatif. Jenis penelitian yang digunakan adalah penelitian explanatory (penjelasan). Singarimbun (1995) menyebutkan bahwa penelitian explanatory yaitu apabila untuk data yang sama peneliti menjelaskan hubungan kausal antara variabel-variabel hipotesa.

\section{Ruang Lingkup Penelitian}

1. Penelitian ini dilakukan untuk menganalisis variabel-variabel yang mempengaruhi perubahan saham LQ45 di Bursa Efek Jakarta dengan menggunakan Model Koreksi Kesalahan (Error Correction Model-ECM).

2. Variabel-variabel yang diduga mempengaruhi harga saham antara lain pertumbuhan ekonomi, tingkat bunga SBI dan kurs Rupiah terhadap Dolar AS serta harga minyak.

3. Periode penelitian adalah bulan Januari 2003 sampai dengan Maret 2009. 


\section{Journal of Indonesian Applied Economics}

Vol. 4 No. 1 Mei 2010, 11-25

\section{Definisi Operasional Variabel}

Dalam penelitian ini variabel-variabel yang dikaji adalah:

1. Variabel terikat/Dependent Variable (Y)

Variabel terikat adalah variabel yang dipengaruhi atau disebabkan oleh variabel lain. Adapun variabel yang digunakan sebagai variabel terikat (Y) adalah saham LQ45. Data yang digunakan adalah data nilai transaksi, yakni hasil dari perkalian antara jumlah saham yang diterbitkan dengan harga saham. Periode yang digunakan dalam penelitian ini adalah periode bulanan dari Januari 2003 sampai dengan Maret 2009.

2. Variabel bebas/Independent Variable (X)

Variabel bebas adalah variabel yang mempengaruhi atau sering disebut variabel yang menjadi penyebab.

a) Pertumbuhan Ekonomi $\left(\mathrm{X}_{1}\right)$. Data pertumbuhan ekonomi (GDP) yang diambil adalah data bulanan dari Januari 2003 sampai Maret 2009.

b) Tingkat Bunga SBI $\left(\mathrm{X}_{2}\right)$.

Data menggunakan data bulanan dan diperoleh dari laporan Bank Indonesia periode Januari 2003 sampai dengan Maret 2009.

c) Kurs Rupiah terhadap Dolar AS $\left(\mathrm{X}_{3}\right)$.

Data diambil secara bulanan dari Januari 2003 sampai Maret 2009 dari Laporan Bank Indonesia.

d) Harga Minyak $\left(\mathrm{X}_{4}\right)$.

Harga minyak yang digunakan dalam penelitian ini adalah harga minyak mentah dalam satuan barel periode bulanan dari Januari 2003 sampai Maret 2009.

\section{Populasi}

Data yang digunakan dalam penelitian ini adalah berupa data populasi (universe). Populasi dalam penelitian ini adalah indeks LQ45 di Bursa Efek Jakarta.

\section{Jenis Data}

Di dalam sebuah penelitian data yang biasanya sering digunakan adalah data primer dan data sekunder, dalam penelitian ini data yang digunakan adalah data sekunder. Supranto (1992) mendefinisikan data sekunder sebagai data yang diperoleh dalam bentuk jadi yang berupa publikasi. Data sudah dikumpulkan oleh instansi atau pihak lain.

\section{Metode Analisis}

Pada penelitian ini digunakan metode kuantitatif Error Correction Model (ECM). Dengan menggunakan teknik ini dapat dianalisis hubungan jangka panjang dan jangka pendek antara variabel dependent dan variabel independent-nya disertai teknik analisis untuk mengoreksi ketidakseimbangan jangka pendek menuju pada keseimbangan jangka panjangnya (speed of adjustment). Selain itu pula hasil analisis yang diharapkan dapat sesuai dengan teori-teori dan asumsi-asumsi yang dibangun (teoritic).

\section{Analisis Data}

Langkah awal yang harus dilakukan adalah menguji akar/stasioneritas data. Uji Akar-akar unit bisa dikatakan sebagai uji stasioner karena pada prinsipnya, uji ini dilakukan untuk mengamati apakah koefisien tertentu dari model otoregresif yang ditaksir mempunyai nilai yang sama atau tidak. Hal ini dilakukan karena sebelum melakukan uji kointegrasi, perilaku data time series harus diamati dengan uji akar-akar unit. Sebab, perilaku data runtun waktu (time series) atau integrsainya dapat dipandang sebagai uji prasyarat dalam penggunaan pendekatan kointegrasi.

Langkah selanjutnya dalah Uji Derajat Integrasi. Uji ini digunakan apabila pada uji akar-akar 


\section{Analisis Pengaruh Faktor Fundamental Ekonomi \\ Prasetiono}

tidak stasioner, atau dengan kata lain untuk mengetahui pada derajat berapa data yang diamati akan stasioner. Uji ini merupakan perluasan dari uji akar-akar unit yang ditaksir dengan model otoregresif.

Model awal yang digunakan dalam penelitian ini adalah sebagai berikut:

$\mathrm{Y}=\mathrm{a}+\mathrm{b}_{1} \mathrm{X}_{1}+\mathrm{b}_{2} \mathrm{X}_{2}+\mathrm{b}_{3} \mathrm{X}_{3}+\mathrm{b}_{4} \mathrm{X}_{4}+\mathrm{e}$

Setelah menentukan model awal analisis, selanjutnya adalah mencari nilai residual yang dari model yang kemudian dinamakan dengan Error Correction Term (ECT).Uji selanjutnya adalah kointegrasi yang merupakan kelanjutan dari uji akar-akar unit dan uji derajat integrasi. Uji kointegrasi dimaksudkan untuk menguji apakah residual regresi (ECT) yang dihasilkan stasioner atau tidak (Engle dan Granger, 1987). Dalam melakukan uji kointegrasi harus diketahui terlebih dahulu apakah data-data yang digunakan telah stasioner serta memiliki derajat integrasi yang sama.

\section{Model Koreksi Kesalahan (ECM)}

Pendekatan atau model koreksi kesalahan (Error Correction Model - ECM) telah diterapkan secara luas dalam analisis ekonometrika untuk data runtun waktu (time series) sejak tahun 1960an. Hal ini disebabkan karena kemampuan yang dimiliki oleh ECM dalam meliput lebih banyak variabel untuk menganalisis fenomena ekonomi jangka pendek dan jangka panjang dan mengkaji konsisten tidaknya model empirik dengan teori ekonomika, serta dalam usaha mencari pemecahan terhadap persoalan variabel runtun waktu yang tidak stasioner (non stationary) dan regresi lancung (spurious regression) atau korelasi lancung (spurious correlation) dalam analisis ekonometrika (Insukindro, 1999).

ECM mempunyai ciri khas dengan dimasukkannya unsur Error Correction Term (ECT) dalam model. Apabila koefisien $E C T$ signifikan secara statistik, maka spesifikasi model yang digunakan dalam penelitian tersebut adalah sahih atau valid. Semua penjelasan di atas, maka dapat dituliskan persamaan ECM sesuai dengan hipotesis, yaitu:

$$
\begin{aligned}
& D Y_{t}=a+b_{1} D X 1_{t}+b_{2} D X 2_{t}+b_{3} D X 3_{t}+b_{4} D X 4_{t}+b_{5} X 1_{t-1}+b_{6} X_{t-1}+b_{7} X 3_{t-1}+
\end{aligned}
$$

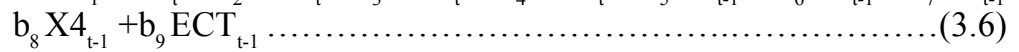

\section{Uji Asumsi Klasik}

\section{Heteroskedastisitas}

Uji gejala heteroskedastisitas bertujuan untuk menguji apakah dalam model regresi terjadi ketidaksamaan variance $\left(\mathrm{s}^{2}\right)$ dari residual satu pengamatan ke pengamatan yang lainnya. Jika variance $\left(\mathrm{s}^{2}\right)$ dari residual satu pengamatan ke pengamatan lainnya tetap, maka disebut homokedastisitas dan jika berbeda disebut heteroskedastisitas. Model regresi yang baik adalah yang homokedastisitas atau tidak terjadi heteroskedastisitas.

\section{Autokorelasi}

Menunjukkan adanya hubungan linier diantara anggota-anggota dari serangkaian pengamatan yang tersusun dalam rangkaian waktu, seperti dalam data runtut waktu (time series) atau dalam rangkaian ruang (seperti dalam data cross-section).

\section{E. HASIL DAN PEMBAHASAN}

\section{Fluktuasi Saham LQ45, GDP, Nilai Tukar, Tingkat Bunga SBI dan Harga Minyak}

Indeks LQ45 dibentuk melalui beberapa kriteria pemilihan antar lain:

1. Masuk dalam top 60 dari total transaksi di pasar regular (rata-rata transaksi dalam 12 bulan terakhir).

2. Masuk dalam rangking yang didasarkan pada nilai kapitalisasi pasar (rata-rata transaksi dalam 12 bulan terakhir). 
3. Telah tercatat di BEJ sekurang-kurangnya tiga bulan terakhir.

4. Kondisi keuangan perusahaan, prospek pertumbuhan, frekuensi dan jumlah transaksi yang tinggi di pasar regular.

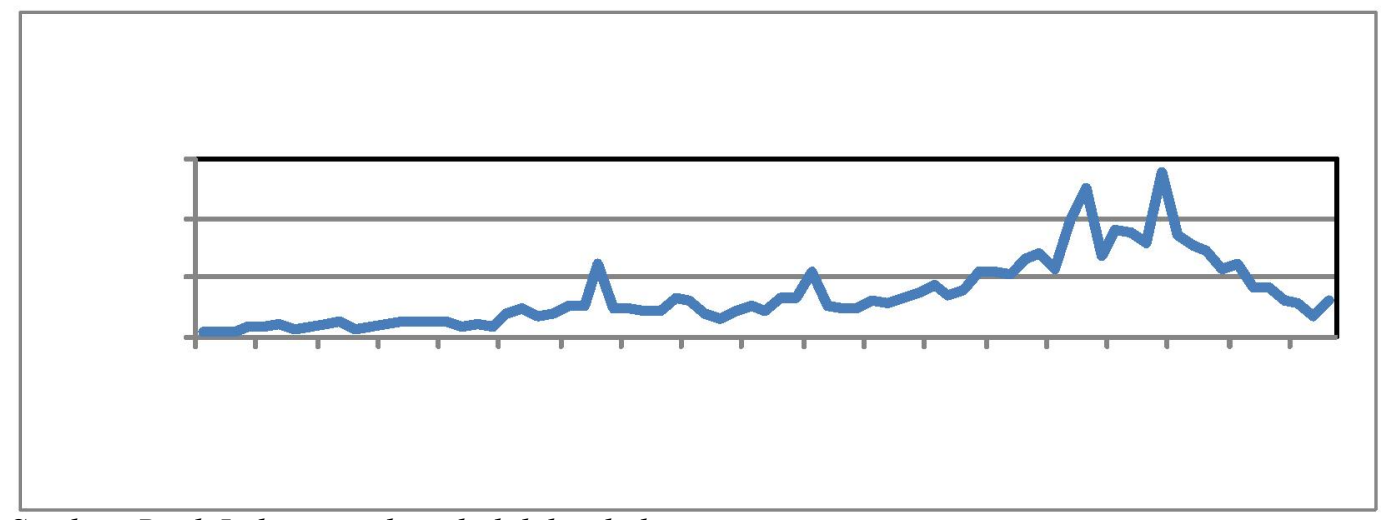

Sumber: Bank Indonesia, data diolah kembali

\section{Gambar 1. Perkembangan saham LQ45 (Nilai Transaksi Dalam Milyar Rupiah)}

Perkembangan saham LQ45 selama periode Januari 2003 sampai Mei 2009 sangat berfluktuasi, dimana perkembangan saham LQ45 mengalami kenaikan dan penurunan. Selama kurun waktu penelitian rekor tertinggi saham LQ45 terjadi pada bulan April 2008 yakni mencapai 138.657 milyar rupiah dan rekor terendah terjadi pada bulan Januari 2003 yakni hanya 3.125 milyar rupiah.

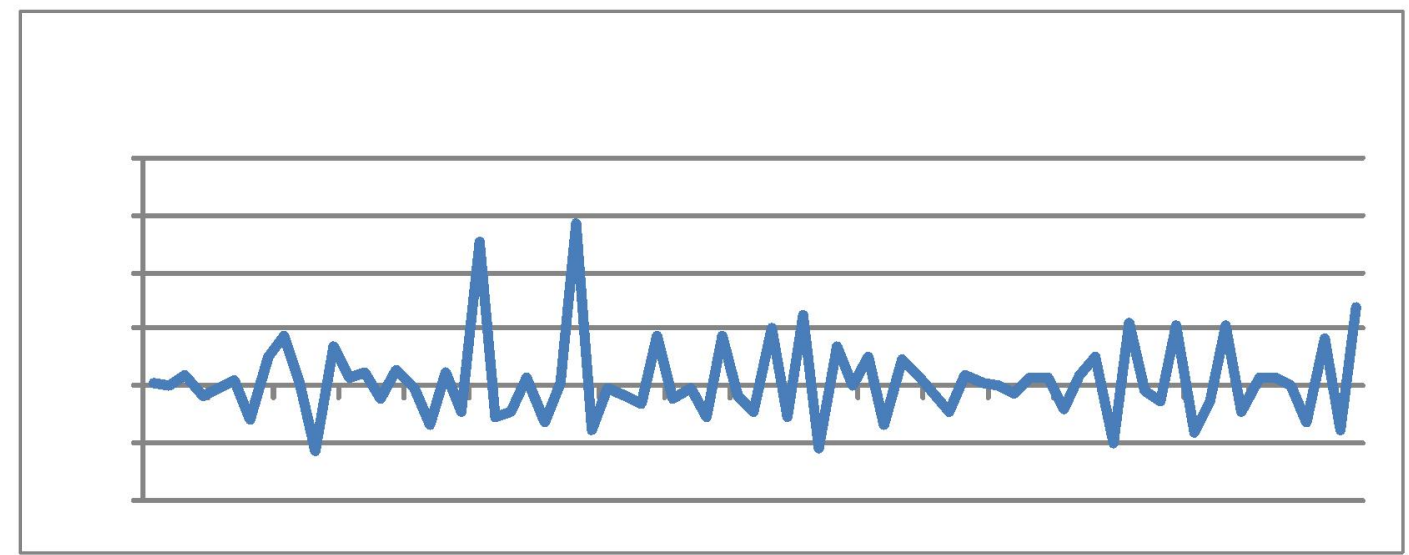

Sumber: Badan Pusat Statistik, data diolah kembali

Gambar 2. Pertumbuhan ekonomi (\%)

Pertumbuhan ekonomi Indonesia selama periode 2003 sampai Maret 2009 terus berfluktuasi. Pertumbuhan ekonomi terendah mencapai 4,78\% di tahun 2003 dan tertinggi di tahun 2007 yang mencapai $6.32 \%$. 


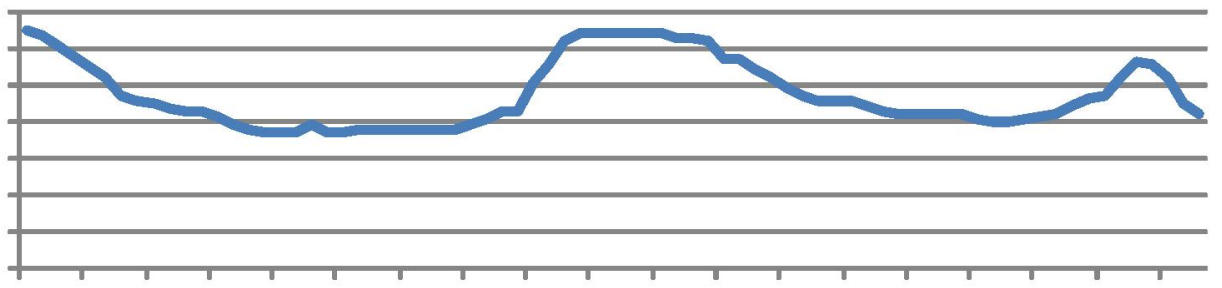

Sumber: Bank Indonesia, data diolah kembali

\section{Gambar 3. Perkembangan Suku Bunga (SBI)}

Pergerakan suku bunga SBI mengalami fluktuasi selama periode 2003 sampai Maret 2009. Pada tahun 2003 suku bunga SBI satu bulan tertinggi mencapai $12.89 \%$ dan terendah di tahun 2004 yang hanya $7.43 \%$.

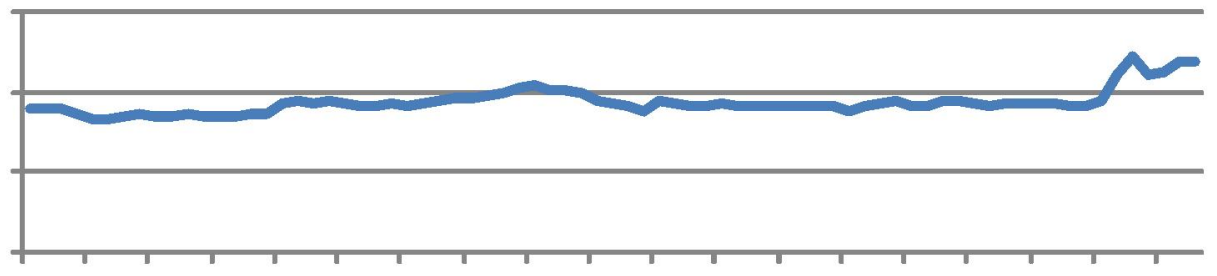

Sumber: Bank Indonesia, data diolah kembali

\section{Gambar 4. Perkembangan nilai tukar (KURS Rp. 000)}

Pergerakan nilai tukar rupiah dari tahun 2003 sampai dengan tahun 2009 terus menguat dengan volatilitas menurun. Nilai tukar Rupiah dengan apresiasi tertinggi mencapai Rp.8.441/US\$ di tahun 2004 dan mengalami penurunan terendah mencapai Rp.11.000/US\$ di awal tahun 2009. 


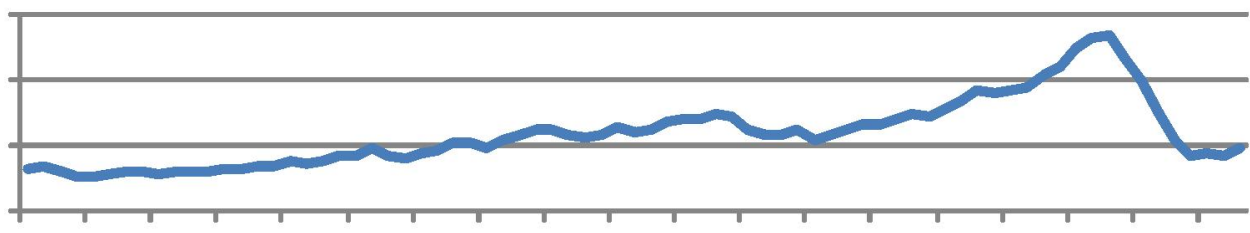

Sumber: Indeks Mundi, data diolah kembali

\section{Gambar 5. Perkembangan Harga Minyak (US\$/Barel)}

Pergerakan harga minyak mentah dunia dari tahun 2003 hingga awal tahun 2009 terus mengalami fluktuasi. Tahun 2003 harga minyak mencapai 29,95 US\$/Barel yang merupakan harga terendah dan di tahun 2008 mencapai 132,55 US\$/Barel dan merupakan harga minyak tertinggi sepanjang sejarah.

\section{Analisis Model Empiris dalam Bentuk Model Linier Dinamik}

\section{Uji Stasioneritas dan Uji Derajat Integrasi}

Uji akar-akar unit yang dilakukan terhadap data saham LQ45, data pertumbuhan ekonomi, tingkat bunga SBI, kurs dan harga minyak menggunakan taraf signifikan (significance level) $5 \%$. Anggapan stasioner diterima bila nilai absolut Augmented Dickey-Fuller Statistic variabel-variabel tersebut lebih besar bila dibandingkan dengan nilai kritisnya (MacKinnon Critical Value).

\section{Tabel 1. Hasil Uji Akar Unit, Derajat Integrasi}

\begin{tabular}{l|l|l|l|l}
\hline \multicolumn{1}{c|}{ Variabel } & \multicolumn{1}{|c|}{ Level } & ADF Test & ADF 5\% & \multicolumn{1}{|c}{ Keterangan } \\
\hline LQ45 & Level & -1.883145 & -2.901779 & Tidak Stasioner \\
& $1^{\text {st }}$ Differencing & -9.107139 & -2.902358 & Stasioner \\
Pertumbuhan Ekonomi & Level & -0.943102 & -2.906210 & Tidak Stasioner \\
\hline & $1^{\text {st }}$ Differencing & -7.825763 & -2.906210 & Stasioner \\
\hline Bunga & Level & -2.604222 & -2.901779 & Tidak Stasioner \\
& $1^{\text {st }}$ Differencing & -3.900029 & -2.901779 & Stasioner \\
\hline Kurs & Level & -0.500238 & -2.901217 & Tidak Stasioner \\
\hline & $1^{\text {st }}$ Differencing & -7.873983 & -2.902358 & Stasioner \\
\hline Harga Minyak & Level & -2.190675 & -2.901779 & Tidak Stasioner \\
& $1^{\text {st } \text { Differencing }}$ & -4.429518 & -2.901779 & Stasioner \\
\hline
\end{tabular}

Sumber: Lampiran 2

\section{Analisis Regresi Linier}

Pengolahan data menggunakan bantuan perangkat software Eviews dan didapatkan hasil analisa model pada tabel 2 .

\section{Uji Kointegrasi}

Pengujian kointegrasi pada residual (ECT) menggunakan model Augmented Dickey-Fuller (ADF). Hasilnya adalah membandingkan ADF statistik nilai kritisnya dengan taraf signifikansi $5 \%$. jika nilai ADF statistik > nilai kritis, maka mengindikasikan terjadi kointegrasi antar variabel. Hasil yang diperoleh adalah nilai ADF statistik sebesar $-4.408316>-2.901217$, sehingga terjadi kointegrasi antar variabel hasil regresi antara pertumbuhan ekonomi, suku bunga SBI, kurs dan 
harga minyak terhadap saham LQ45. Hal ini mengindikasikan variabel tersebut dikatakan dalam kondisi keseimbangan jangka panjang (long-run equilibrium), sehingga hasil regresi adalah regresi yang terkointegrasi.

\section{Tabel 2. Hasil Uji Linier Berganda}

\begin{tabular}{c|c|cc|l}
\hline \multicolumn{1}{c|}{ Va riabel } & \multicolumn{1}{|c|}{ B } & \multicolumn{1}{c|}{ t } & Sig t & \multicolumn{1}{c}{ Keterangan } \\
\hline Konstanta & -4.480715 & & & \\
GDP & 0.082546 & 4.975987 & 0.0000 & Signifikan \\
Bunga & -3.190583 & -3.734394 & 0.0004 & Signifikan \\
\hline Kurs & -1.641628 & 0.795370 & 0.4291 & Tidak Signifikan \\
\hline Minyak & 0.805222 & 12.29039 & 0.0000 & Signifikan \\
$\mathrm{t}_{\text {tabel }}$ & $=$ & 2.00 & & \\
\hline $\mathrm{R} \mathrm{Square}$ & $=$ & 0.796407 & & \\
\hline $\mathrm{F}_{\text {hinng }}$ & $=$ & 68.45568 & \\
\hline Sig F & $=$ & 0.000 & & \\
$\mathrm{~F}_{\text {tabel }}$ & $=$ & 2.54 & & \\
\hline Sumber: Lampiran 2 & & &
\end{tabular}

Sumber: Lampiran 2

\section{Analisis Estimasi Model Linier Dinamik Error Correction Model (ECM)}

Berikut ini akan disajikan tabel 3 yang merupakan hasil dari estimasi pada perhitungan pengujian model dinamis (ECM):

\section{Tabel 3. Hasil Uji ECM}

\begin{tabular}{|c|c|c|c|c|}
\hline \multicolumn{5}{|c|}{ Dependent Variable: D(LQ45) } \\
\hline \multicolumn{5}{|c|}{ Method: Least Squares } \\
\hline \multicolumn{5}{|c|}{ Date: 10/17/09 Time: 07:01 } \\
\hline \multicolumn{5}{|c|}{ Sample(adjusted): 2003:02 2009:03 } \\
\hline \multicolumn{5}{|c|}{ Inclu ded observations: 74 after adjusting endpoints } \\
\hline Variable & Coefficient & Std. Error & t-Statistic & Prob. \\
\hline $\mathrm{C}$ & -3.468545 & 19.24332 & -0.180247 & 0.8575 \\
\hline $\mathrm{D}(\mathrm{GDP})$ & 0.086905 & 0.014667 & 5.925177 & 0.0000 \\
\hline D(BUNGA) & -3.807768 & 3.296555 & -1.155075 & 0.2524 \\
\hline D(KURS) & -2.702003 & 4.383666 & -0.616380 & 0.5398 \\
\hline D(MINY AK) & 0.586741 & 0.256480 & 2.287671 & 0.0255 \\
\hline GDP(-1) & 0.021053 & 0.023213 & 0.906968 & 0.3678 \\
\hline BUNGA(-1) & -0.045877 & 0.782057 & -0.058663 & 0.9534 \\
\hline KURS(-1) & -0.322581 & 1.975319 & -0.163306 & 0.8708 \\
\hline MINYAK(-1) & -0.049589 & 0.065531 & -0.756728 & 0.4520 \\
\hline $\operatorname{ECT}(-1)$ & -0.390172 & 0.117024 & -3.334117 & 0.0014 \\
\hline R-squared & 0.597216 & \multicolumn{2}{|c|}{ Mean dependent var } & 0.353770 \\
\hline Adjusted R-squared & 0.540575 & \multicolumn{2}{|c|}{ S.D. dependent var } & 16.53671 \\
\hline S.E. of regression & 11.20873 & \multicolumn{2}{|c|}{ Akaike info criterion } & 7.796352 \\
\hline Sum squared resid & 8040.686 & \multicolumn{2}{|c|}{ Schwarz criterion } & 8.107712 \\
\hline Log likelihood & -278.4650 & \multicolumn{2}{|c|}{ F-statistic } & 10.54380 \\
\hline Durbin-Watson stat & 2.124058 & \multicolumn{2}{|c|}{$\operatorname{Prob}$ (F-statistic) } & 0.000000 \\
\hline
\end{tabular}

Sumber: Lampiran 2

Berdasarkan hasil estimasi pada tabel 3 dapat diinterpretasikan bahwa variabel independen pertumbuhan ekonomi dan harga minyak memiliki pengaruh yang signifikan terhadap variabel dependen LQ45, sedangkan variabel independen lain yaitu suku bunga SBI dan kurs tidak memiliki pengaruh yang signifikan. Hasil yang diperoleh adalah nilai $\mathrm{R}^{2}=0.597216$, angka ini menunjukkan bahwa $59.72 \%$ variabel dependen dijelaskan oleh variabel independen dan sisanya $40.28 \%$ dijelaskan oleh variabel diluar variabel independen yang digunakan. Nilai probabilitas $f_{\text {statistik }}$ yang signifikan, menunjukkan bahwa secara bersama-sama variabel independen mempunyai pengaruh yang signifikan terhadap variabel dependen.

Dari tabel 3 di atas terlihat bahwa koefisien ECT memiliki nilai $t_{\text {hitung }}$ sebesar 3.334117, sedangkan nilai $t_{\text {tabel }}$ adalah 2.00. karena nilai $t_{\text {hitung }}$ lebih besar dari $t_{\text {tabel }}$, maka dapat disimpulkan bahwa 
penggunaan model ECM dalam penelitian ini adalah sahih, sehingga dapat digunakan untuk mengestimasi pengaruh variabel bebas terhadap variabel terikat baik dalam jangka pendek maupun jangka panjang.

\section{Interpretasi Hasil Estimasi Jangka Pendek}

Dari tabel 3, maka dapat ditulis persamaan model saham LQ45 adalah sebagai berikut: $\mathrm{Y}=-3.468545+0.086905 \mathrm{X}_{1}-3.807768 \mathrm{X}_{2}-2.702003 \mathrm{X}_{3}+0.586741 \mathrm{X}_{4}$

Interpretasi dari hasil estimasi jangka pendek tersebut di atas adalah sebagai berikut:

1. Koefisien pertumbuhan ekonomi $\left(\mathrm{X}_{1}\right)$ terhadap saham LQ45 (Y) adalah positif dengan nilai koefisien 0.086905. Hal ini menunjukkan bahwa jika terjadi kenaikan pertumbuhan ekonomi $\left(\mathrm{X}_{1}\right)$ sebesar 1 persen (ceteris paribus), maka akan menyebabkan kenaikan saham sebesar $0.086905 \%$.

2. Koefisien suku bunga SBI $\left(\mathrm{X}_{2}\right)$ terhadap saham LQ45 (Y) adalah negatif dengan nilai koefisien -3.807768. Hal ini menunjukkan bahwa jika terjadi kenaikan suku bunga SBI $\left(\mathrm{X}_{2}\right)$ sebesar 1 persen (ceteris Paribus), maka akan mengakibatkan penurunan saham (Y) LQ45 sebesar $3.807768 \%$.

3. Koefisien kurs $\left(\mathrm{X}_{3}\right)$ terhadap saham LQ45 (Y) adalah negatif dengan koefisien -2.702003. Hal ini menunjukkan bahwa jika terjadi kenaikan kurs $\left(\mathrm{X}_{3}\right)$ sebesar 1 persen (ceteris paribus), maka akan menurunkan saham (Y) LQ45 sebesar 2.702003\%.

4. Koefisien harga minyak terhadap $\left(\mathrm{X}_{4}\right)$ terhadap saham LQ45 $(\mathrm{Y})$ adalah positif dengan nilai 0.586741. Hal ini menunjukkan bahwa jika terjadi kenaikan harga minyak $\left(\mathrm{X}_{4}\right)$ sebesar 1 persen (ceteris paribus), maka akan menyebabkan kenaikan saham LQ45 (Y) sebesar $0.586741 \%$.

\section{Interpretasi Hasil Estimasi Jangka Panjang}

Untuk mendapatkan koefisien jangka panjang model ECM, maka akan dihitung dengan menggunakan rumus:

Konstanta $=\mathrm{b}_{0} / 1-\mathrm{b}_{9}$

Pertumbuhan ekonomi $=b_{5}+b_{9} / 1-b_{9}$

Suku bunga $\mathrm{SBI}=\mathrm{b}_{6}+\mathrm{b}_{9} / 1-\mathrm{b}_{9}$

Kurs $=b_{7}+b_{9} / 1-b_{9}$

Harga minyak $=b_{8}+b_{9} / 1-b_{9}$

Tabel 4. Model Estimasi Jangka Panjang

\begin{tabular}{lc}
\hline \multicolumn{1}{c}{ Variabel bebas } & Koefisien Regresi \\
\hline Konstanta & -5.68774 \\
Pertumbuhan ekonomi & -0.60528 \\
Suku bunga SBI & -0.71504 \\
Kurs & -1.16878 \\
\hline Harga minyak & -0.72112 \\
\hline
\end{tabular}

Dari tabel 4.4 di atas dapat dibuat model persamaan untuk jangka panjang adalah sebagai berikut: $\mathrm{Y}=-5.68774-0.60528 \mathrm{X}_{1}-0.71504 \mathrm{X}_{2}-1.16878 \mathrm{X}_{3}-0.72112 \mathrm{X}_{4}$

Interpretasi dari hasil estimasi jangka panjang model ECM dapat dijelaskan sebagai berikut:

1. Koefisien pertumbuhan ekonomi $\left(\mathrm{X}_{1}\right)$ terhadap saham LQ45 (Y) adalah negatif dengan nilai koefisien -0.60528. Hal ini menunjukkan bahwa jika terjadi kenaikan pertumbuhan ekonomi $\left(\mathrm{X}_{1}\right)$ sebesar 1 persen (ceteris paribus), maka akan menyebabkan penurunan saham sebesar $0.60528 \%$.

2. Koefisien suku bunga $\mathrm{SBI}\left(\mathrm{X}_{2}\right)$ terhadap saham $\mathrm{LQ} 45(\mathrm{Y})$ adalah negatif dengan nilai koefisien -0.71504. Hal ini menunjukkan bahwa jika terjadi kenaikan suku bunga SBI $\left(\mathrm{X}_{2}\right)$ sebesar 1 persen (ceteris Paribus), maka akan mengakibatkan penurunan saham (Y) LQ45 sebesar 


\section{Analisis Pengaruh Faktor Fundamental Ekonomi}

Prasetiono

$0.71504 \%$.

3. Koefisien kurs $\left(\mathrm{X}_{3}\right)$ terhadap saham LQ45 $(\mathrm{Y})$ adalah negatif dengan koefisien -1.16878. Hal ini menunjukkan bahwa jika terjadi kenaikan kurs $\left(\mathrm{X}_{3}\right)$ sebesar 1 persen (ceteris paribus), maka akan menurunkan saham (Y) LQ45 sebesar 1.16878\%.

4. Koefisien harga minyak terhadap $\left(\mathrm{X}_{4}\right)$ terhadap saham LQ45 $(\mathrm{Y})$ adalah positif dengan nilai -0.72112. Hal ini menunjukkan bahwa jika terjadi kenaikan harga minyak $\left(\mathrm{X}_{4}\right)$ sebesar 1 persen (ceteris paribus), maka akan menyebabkan penurunan saham LQ45 (Y) sebesar $0.72112 \%$.

\section{Hasil Uji Asumsi Klasik}

Di bawah ini disajikan hasil pengujian asumsi klasik terhadap model linier dinamik ECM yang digunakan dalam penelitian ini (persamaan 3.6). Uji yang dilakukan adalah uji heteroskedastisitas dan uji autokorelasi.

\section{Uji Heteroskedastisitas}

Berdasarkan hasil estimasi dengan menggunakan uji White Heteroskedasticity (no cross term), maka dapat disimpulkan bahwa hipotesis nol yang menyatakan bahwa tidak terdapat masalah heteroskedastisitas dapat diterima. Hal ini disebabkan karena nilai probabilitas $O b s * R$-Squared $\left(\mathrm{c}^{2}{ }_{\text {hitung }}\right)$ sebesar 0.137 jauh lebih besar bila dibandingkan dengan taraf signifikansi 5 persen $(0.05)$.

\section{Uji Autokorelasi}

Berdasarkan hasil Uji Lagrange Multiplier (LM Test), diperoleh nilai probabilitas $O b s * R$-Squared $\left(\mathrm{c}^{2}{ }_{\text {hitung }}\right)$ sebesar $0.364>$ taraf signifikansi 5 persen $(0.05)$. Dengan demikian, berdasarkan perbandingan nilai tersebut, dapat disimpulkan bahwa hipotesis nol $\left(\mathrm{H}_{0}\right)$ yang menyatakan tidak terdapat masalah autokorelasi dalam model empiris yang digunakan dapat diterima, yang berarti bahwa tidak ditemukan adanya autokorelasi dalam model yang digunakan.

\section{Analisis Ekonomi Model Koreksi Kesalahan}

1. Variabel Pertumbuhan Ekonomi

Sebagai salah satu variabel ekonomi makro yang mempengaruhi saham LQ45, pertumbuhan ekonomi memiliki pengaruh yang signifikan dalam jangka pendek dengan koefisien positif, namun tidak dalam jangka panjang yang mempunyai koefisien negatif dengan pengaruh yang tidak signifikan. Keadaan ini disebabkan karena dalam jangka pendek investor berharap dengan adanya pertumbuhan ekonomi yang positif akan mampu meningkatkan return yang akan diperoleh. Pengaruh tidak signifikan dalam jangka panjang disebabkan karena situasi dalam negeri yang ada (seperti kerusuhan, tragedi bom, faktor politik, dsb) yang dapat mengakibatkan investor enggan menyimpan dananya dalam bentuk saham. Hal ini dikarenakan investor cenderung memprioritaskan resiko yang akan dihadapi daripada return yang akan didapatkan.

2. Variabel Suku Bunga SBI

Hasil yang tidak signifikan dalam jangka pendek dan jangka panjang ditunjukkan oleh variabel bebas suku bunga SBI. Hal ini disebabkan karena perubahan pada suku bunga SBI tidak direspon dengan baik oleh perbankan secara umum yang merupakan konsekuensi dari kebijakan moneter yang ketat yang ada di negara ini. Selain itu, mungkin juga disebabkan fungsi intermediasi dari perbankan belum berjalan dengan baik, sehingga kecepatan dari merespon perubahan yang ada masih terkesan lambat.

3. Variabel Nilai Tukar (kurs)

Hasil yang serupa juga diperlihatkan oleh variabel nilai tukar yakni tidak signifikan dalam jangka pendek dan jangka panjang dengan koefisien negatif. Dengan hasil ini menginterpretasikan bahwa dengan melemahnya nilai tukar atau nilai mata uang domestik 
dapat mengakibatkan kerugian pada pasar modal dalam negeri baik dalam jangka pendek maupun jangka panjang. Dengan nilai impor yang signifikan pada negara kita, pengaruh dari depresiasi mata uang akan menyebabkan pasar saham kurang peminat dalam jangka panjang. Dalam jangka pendek, depresiasi mata uang domestik akan mengakibatkan inflasi yang merupakan sinyal negatif bagi pasar saham.

4. Variabel Harga Minyak

Variabel harga minyak memiliki pengaruh yang signifikan dalam jangka pendek dan tidak signifikan dalam jangka panjang dengan koefisien positif dalam jangka pendek dan negatif dalam jangka panjang. Hal ini disebabkan karena negara ini merupakan negara penghasil minyak, sehingga dengan adanya kenaikan harga minyak akan meningkatkan pertumbuhan ekonomi yang kemudian akan meningkatkan pendapatan masyarakat yang pada akhirnya meningkatkan permintaan akan produk perusahaan dan harga saham. Dalam jangka panjang, hubungan antara harga minyak dan saham menjadi negatif yang disebabkan karena kenaikan harga minyak lama kelamaan akan meningkatkan biaya operasional dari perusahaan. Dengan kenaikan biaya akan menaikkan harga dari output yang kemudian menurunkan permintaan dan juga keuntungan yang akan diperoleh perusahaan.

\section{Keterbatasan Penelitian}

Penelitian ini mempunyai beberapa keterbatasan, yaitu:

1. Penelitian ini hanya menganalisis pengaruh variabel makro ekonomi terhadap saham LQ45. Faktor-faktor lain yang mungkin mempengaruhi harga saham seperti masalah politik, tingkat pendapatan nasional, pembagian deviden dan faktor-faktor internal lain, tidak dimasukkan dalam penelitian ini.

2. Dalam rentang waktu 6 tahun 3 bulan penelitian, terdapat kemungkinan adanya peristiwa atau faktor lain yang mempengaruhi saham LQ45.

3. Penelitian ini menggunakan data bulanan. Oleh karena itu, hasil penelitian ini belum dapat mengungkap lebih jauh pengaruh variabel makro ekonomi terhadap saham LQ45, khususnya untuk jangka pendek.

\section{E. KESIMPULAN DAN REKOMENDASI}

\section{Kesimpulan}

Tujuan dari penelitian ini adalah untuk mengetahui pengaruh variabel makro ekonomi terhadap saham LQ45 di Indonesia selama periode 2003:01-2009:03 dengan menggunakan Model Linier Dinamik Error Correction Model (ECM). Dalam analisis pengaruh variabel ekonomi makro terhadap saham LQ45 secara umum, disimpulkan bahwa dalam jangka pendek variabel pertumbuhan ekonomi dan harga minyak mempunyai pengaruh yang signifikan terhadap saham LQ45, tetapi tidak untuk variabel suku bunga SBI dan kurs yang tidak signifikan. Dalam jangka panjang semua variabel bebas yang digunakan tidak memiliki pengaruh yang signifikan terhadap saham LQ45.

Berdasarkan nilai koefisien masing-masing variabel dapat disimpulkan bahwa jika dalam jangka pendek pertumbuhan ekonomi dan harga minyak mengalami perubahan sebesar 1 persen maka saham LQ45 akan mengalami perubahan sebesar 0.09 persen dan 0.59 persen dengan arah perubahan yang searah dengan perubahan pertumbuhan ekonomi dan harga minyak. Sedangkan perubahan kurs dan suku bunga SBI sebesar 1 persen akan mengakibatkan perubahan saham LQ45 sebesar 2.7 persen dan 3.81 persen dengan arah perubahan yang berlawanan dengan perubahan kurs dan suku bunga SBI.

Berdasarkan hasil perhitungan koefisien jangka panjang dari persamaan ECM di atas, dapat dikemukakan bahwa dalam jangka panjang setiap perubahan pertumbuhan ekonomi dan suku bunga SBI sebesar 1 persen akan mengakibatkan perubahan pada saham LQ45 sebesar 0.6 persen dan 0.7 persen dengan arah perubahan yang berlawanan dengan perubahan pertumbuhan ekonomi dan 
tingkat bunga SBI. Sedangkan perubahan kurs dan harga minyak sebesar 1 persen, dalam jangka panjang akan mengakibatkan perubahan saham LQ45 sebesar 1.17 persen dan 0.72 persen dengan arah perubahan yang berlawanan dengan perubahan kurs dan harga minyak. Berdasarkan hasil estimasi, dapat kita lihat pula variabel bebas yang mempunyai pengaruh paling dominan terhadap saham LQ45, dimana dalam jangka pendek suku bunga SBI memiliki pengaruh yang paling dominan. Sedangkan dalam jangka panjang, variabel kurs mempunyai pengaruh yang paling besar (dominan) terhadap saham LQ45.

\section{Rekomendasi}

1. Bagi para investor, perlu mempertimbangkan lebih jauh pengaruh faktor-faktor pertumbuhan ekonomi, tingkat bunga SBI, nilai tukar (kurs) dan harga minyak selain faktor-faktor lain yang juga perlu dipertimbangkan.

2. Bagi pasar modal, penelitian ini menunjukkan bahwa variabel pertumbuhan ekonomi dan harga minyak mempunyai pengaruh yang signifikan terhadap saham LQ45 dalam jangka pendek.

3. Bagi peneliti lain yang ingin melakukan penelitian dengan tema yang sama, disarankan untuk mempertimbangkan sejumlah keterbatasan yang terdapat dalam penelitian ini, khususnya mengenai pemilihan range data. Untuk penelitian berikutnya disarankan untuk menggunakan data harian atau mingguan, agar dapat mengungkap lebih jauh pengaruh variabel makro ekonomi terhadap saham, khususnya dalam jangka pendek.

4. Bagi dunia pendidikan (Universitas), diharapkan lebih memperhatikan sarana dan prasarana seperti tenaga pengajar, kurikulum termasuk silabus, buku maupun jurnal penelitian, perangkat lunak maupun perangkat keras yang menunjang penelitian khususnya penelitian yang menggunakan Model Dinamik, mengingat model penelitian ini cukup rumit dan kompleks.

\section{DAFTAR PUSTAKA}

Anonim. (1994-2000). Eviews 4 User's Guide. Quantitative Micro Software. United States of America.

Anonim. (2006). Pedoman Penulisan Skripsi Artikel Makalah. Malang. Fakultas Ekonomi Universitas Brawijaya.

Anonim, (2003). Statistik Ekonomi dan Keuangan Indonesia. Jakarta. Bank Indonesia.

, (2004). Statistik Ekonomi dan Keuangan Indonesia. Jakarta. Bank Indonesia.

, (2005). Statistik Ekonomi dan Keuangan Indonesia. Jakarta. Bank Indonesia.

, (2006). Statistik Ekonomi dan Keuangan Indonesia. Jakarta. Bank Indonesia.

, (2007). Statistik Ekonomi dan Keuangan Indonesia. Jakarta. Bank Indonesia.

, (2008). Statistik Ekonomi dan Keuangan Indonesia. Jakarta. Bank Indonesia.

Anoyke dan George Tweneboah. (2008). Do Macroeconomic Variables Play Any Role in The Stock Market Movement in Ghana?. MPRA paper.

Baillie, Richard dan Patrick McMahon. (1990). The Foreign Exchange Market: Theory and Econometric Evidence. Cambridge University Press. Cambridge.

Banerjee, k. Prashanta dan Bishnu k. Adhikary. (2007). Dynamic Effects of Interes Rate and Exchange Rate Change on Stock Market Returns in Bangladesh. Bangladesh Institute of Bank 
Management. Dhaka, Bangladesh.

Chen, N. F., R. Roll dan S. Ross. (1986). Economic Forces and the Stock Market. Journal of Business 59 (3).

Dahlan, Siamat. (2001). Manajemen Lembaga Keuangan. Edisi Ketiga. Jakarta. Lembaga Penerbit Fakultas Ekonomi Universitas Indonesia.

Engle, RF and C.W.J Granger. (1987). "Cointegration and Error Correction Representation, Estimation and Testing". Econometrica.

Gujarati, Damodar. (1995). Basic Econometrics. 3th Ed. Jakarta. Erlangga.

Gunawan dan Adler Manurung. (2008). Pengaruh Komoditas Terhadap Indeks Harga Saham Gabungan. Jurnal Ekonomi dan Bisnis Indonesia.

Harianto, Farid Dr. dan Dr. Siswanto Sudono. (1998). Perangkat dan Teknik Analisis Investasi di Pasar Modal Indonesia. Bursa Efek Jakarta. Jakarta.

Humpe, Andreas and Peter Macmillan. (2007). Can Macroeconomic Variables Explain Long Term Stock Market Movements? A Comparison of the US and Japan. School of Economics and Finance University of St Andrews. St Andrews.

Insukindro. (1999). Pemilihan Model Ekonomi Empirik dengan Pendekatan Koreksi Kesalahan. Jurnal Ekonomi dan Bisnis Indonesia Volume 14 No. 1. Fakultas Ekonomi Universitas Gajah Mada. Yogyakarta.

Kaluge, David. (2006). Analisis Pengaruh Profitabilitas, Suku Bunga, GDP dan Kurs terhadap Harga Saham. Malang. Fakultas Ekonomi Universitas Brawijaya.

Kuncoro, Mudrajad. "Purchasing Power Parity: It's Nature, Deviation, and Implication for International Management”. Kelola Gadjah Mada University Review. hal. 83, No. 7/III/1993.

Lucey, Brian, Ali Nejadmalayery and Manohar Singh. Impact of US Macroeconomic Surprices on Stock Market Returns in Developed Economies.

Mun, Kyung-Chun. The Contribution of Exchange Rate Fluctuations to Stock Market Volatility and Cross-Market Correlations. Division of Business and Accountancy Truman State University. Kirksville.

Nath, Golaka C and G P Samanta. (2003). Relationship Between Exchange Rate and Stock Price in India-An Empirical analysis.

Nopirin, Ph.D. (1992). Ekonomi Moneter. Edisi Keempat. Yogyakarta. BPFE.

Rahardjo, M. D. (1995). Bank Indonesia: Dalam Kilasan Sejarah Bangsa. Jakarta. LP3ES.

Sadewa, Purbaya Yudhi. (2009). "Pergerakan Indeks Bursa Indonesia Tertinggi”. www.Media Indonesia.com, 27-05-2009.

Singarimbun, Masri dan Sofian Effendi. (1995). Metode Penelitian Survey. LP3ES. Jakarta.

Supranto, J. (1992). Statistik Pasar Modal. Rineka Cipta. Jakarta.

Susanto, S. (2002). Peran Fundamental Ekonomi dan Sentimen di bursa Efek. www. Kompas.com.

Tandelilin, E. (2001). Analisis Investasi dan Manajemen Portofolio. Edisi Pertama. Yogyakarta. 


\section{Analisis Pengaruh Faktor Fundamental Ekonomi}

Prasetiono

BPFE.

Weston, J. Fred and Eugene F. Brigham. (1990). Dasar-dasar Manajemen Keuangan. Jilid 2. Cetakan 1. Terjemahan. Alfonsus Sirait, SE, Penerbit Erlangga. Jakarta. 